\title{
KOGNITYWNY MODEL KONCEPTU STRACH W JEZZYKU UKRAIŃSKIM
}

\author{
LUKASZ MAŁECKI \\ Uniwersytet imienia Adama Mickiewicza w Poznaniu, Poznań — Polska \\ КОГНІТИВНА МОДЕЛЬ КОНЦЕПТУ СТРАХ В УКРАЇНСЬКІЙ МОВІ \\ ЛУКАШ МАЛЕЦЬКИЙ \\ Університет імені Адама Міцкевича, Познань - Польща \\ АНОТАЦІЯ. Стаття присвячена дослідженню концепту СТРАХ в українській мов- \\ ній картині світу. На підставі мовного матеріалу й з урахуванням принципів когнітив- \\ ної лігнвістики та “когнітивної дефініції” були виділені семантичні складові концепту \\ та його загальна структура.
}

\section{COGNITIVE MODEL OF THE CONCEPT FEAR IN UKRAINIAN}

\author{
ŁUKASZ MAŁECKI \\ Adam Mickiewicz University in Poznan, Poznań — Poland
}

ABSRACT. The article is dedicated to the investigation of the concept FEAR in the Ukrainian language mapping. Semantic constituents and the general structure of the concept have been determined on the basis of the linguistic material; the principles of cognitive linguistics and cognitive definition have been taken into account.

$\mathrm{W}$ spółczesny okres polifonii nauk humanistycznych, warunkujący dalsze kierunki oraz tendencje ich rozwoju, jest następstwem oraz odzwierciedleniem nowego, dominującego w badaniach podejścia - idei antropocentryzmu. Dynamiczne przemiany, mające swój początek w latach 70-tych XX wieku, do których przylgnęło miano ,rewolucji kognitywnej”, w znacznym stopniu wywarły również wpływ na kształt i przeobrażenia dokonujące się we współczesnym językoznawstwie. Jednym z najprężniej rozwijających się nurtów lingwistyki należy uznać niewątpliwie językoznawstwo kognitywne, wzbudzające tyle samo nadziei i entuzjazmu, co kontrowersji. W ogólnym zarysie jest to kierunek, w centrum zainteresowań którego znajduje się język jako ogólny mechanizm kognitywny, tzn. system znaków, pełniących funkcje interpretacji (kodowania) i transformacji informacji. Językoznawstwo kognitywne — parafrazując słowa Elżbiety Tabakowskiej — ,„...) to propozycja dla ludzi z wyobraźnią. Dla ludzi, którzy — dostrzegając zalety rygorystycznej formalizacji - mimo wszystko chcieliby wyjść poza sztywne ramy strukturalistycznego obiektywizmu, sięgnąć dalej niż sięga „mędrca szkiełko i oko”, którzy w twórcy i użytkowniku języka widzą nie tylko genialny mechanizm do produkowania słów i zdań, ale i kwintesencję jego człowieczeństwa: nieprzewidywalność reakcji, oryginalność spojrzenia na świat, słowem wszystko to, co w połączeniu z uwarunkowaniami kulturowymi i społecznymi decyduje o sposobie, w jaki człowiek używa swojego języka - genialnego narzędzia, którego jest zarówno twórca, jak i niewol- 
nikiem". W ujęciu kognitywistów człowiek, percypując świat, tworzy w swym umyśle struktury pojęciowe, które opierają się na doświadczeniu zmysłowym, fizycznym i społecznym oraz na działalności człowieka. Niektóre z tych zjawisk oraz przedmiotów są przez umysł ludzki pomijane, inne zaś percypowane i interpretowane przez doświadczenie, wyobrażenie i wiedzę człowieka². Rzeczywistość nie jest uporządkowana i podzielona na elementy, nie tworzy w sposób naturalny żadnych klas, modeli czy też kategorii. Dopiero człowiek poprzez swoje doświadczenie klasyfikuje świat, a rezultaty poznawczej działalności człowieka znajdują swoje odzwierciedlenie w języku. Język jest zatem narzędziem mentalnego (kognitywnego) ujmowania świata, otaczającej rzeczywistości, funkcjonujących w niej przedmiotów, zjawisk oraz ludzi. Język nie jest jednak wiernym odzwierciedleniem rzeczywistości, lecz odbiciem sposobu patrzenia człowieka na świat, czyli — jak zauważa Anna Wierzbic$\mathrm{ka}$ - zawiera oraz odwzorowuje on obraz świata takiego, jaki postrzegamy, w jaki wierzymy, nie zaś takiego, jakim ten świat jest rzeczywiście ${ }^{3}$.

Niniejszy artykuł wpisuje się w nurt badań językoznawczych, które traktują język nie tylko jako narzędzie porozumiewania się, środek komunikacji, ale również (czy przede wszystkim) jako źródło wiedzy o samym człowieku i widzianym przez niego świecie; dąży do odsłonięcia zawartych w języku sposobów postrzegania, porządkowania i wartościowania świata.

Nowe tendencje lingwistyczne aktywizowały oraz położyły nacisk na poszukiwanie nowych zagadnień badawczych i metod ich analizowania. Jedną z najbardziej aktualnych kwestii jest niewątpliwie problematyka korelacji i współzależności języka i sfery emocji, jako jednej z form poznawczej działalności jednostki. W psychologii emocje rozpatrywane są jako procesy psychiczne, silne odczucia pobudzające oraz nadające wrażeniom subiektywne wartości i jakości. Są to zwykle automatyczne, dość krótkie i złożone reakcje organizmu.

Emocje to jednak nie tylko wskaźniki różnorodnych stanów psychicznych, świadczących o stosunku człowieka do otaczającego go świata, innych ludzi, zróżnicowanych procesów i jego działalności. W poznawczej działalności jednostki emocje same stają się obiektem odzwierciedlenia, przyjmując formę złożonych mentalnych struktur - konceptów, które częściowo utrwalane i wyrażane są za pomoca języka. Zgodnie z założeniami podejścia kognitywnego jednostki języka rozpatrywane są jako swoisty klucz do prześledzenia i zbadania procesów mentalnych zachodzących w ludzkiej świadomości. To z kolei pozwala przeanalizować sposób postrzegania rzeczywistości przez członków danej wspólnoty językowej i tym samym dokonać rekonstrukcji językowego obrazu świata. Pod pojęciem językowego obrazu świata $\mathrm{w}$ niniejszym artykule rozumiemy ,zawartą w języku, w różny sposób werbalizowana, interpretację rzeczywistości, którą można ująć w postaci zespołu sądów o świecie"4. Jednym ze sposobów rekonstrukcji JOS jest analiza konceptów jako „specyficznych jednostek leksykonu mentalnego”, „kwantów wiedzy”, ,podstawowych komórek kultury". Pod pojęciem konceptu rozumiemy mentalną jednostkę, strukturę przedstawienia wiedzy, informacji, uwarunkowaną kulturowo i społecznie oraz częściowo realizowaną i utrwaloną za pomocą różnych środków językowych.

${ }^{1}$ E. Tabakowska, Gramatyka i obrazowanie. Wprowadzenie do językoznawstwa kognitywnego, Kraków 1999, c. 5.

${ }^{2}$ A. Krawczy k, Jezzyk źródtem wiedzy o człowieku, [w:] "Etnolingwistyka", 1989, Nr 2, s. 29

${ }^{3} \mathrm{~A}$. Wierzbicka, Uniwersalne pojęcia ludzkie i ich konfiguracje w różnych kulturach, [w:] „Etnolingwistyka", 1991, Nr4, s.30.

${ }^{4}$ J. Bartmiński, Językowe podstawy obrazu świata, Lublin 2006, c. 14-15. 
Niniejszy artykuł stanowi próbę rekonstrukcji i analizy niewielkiego fragmentu językowego obrazu świata - konceptu STRACH, zawierającego wyobrażenia i informację o jednej z głównych emocji - strachu.

Zgodnie z założeniami teorii kognitywnej, podstawowy problem badawczy w języku stanowi znaczenie rozumiane jako konceptualizacja. Według kognitywistów język jest „bezpośrednim odbiciem procesów poznawczych, które zachodzą w umyśle człowieka i stanowią wobec tego inherentne elementy ludzkiego poznania"'5. Powiązanie języka z ludzkimi procesami poznawczymi, z doświadczeniem i wiedzą o świecie doprowadziło do zniesienia granicy pomiędzy zdolnościami językowymi i pozajęzykowymi, wiedzą językową i pozajęzykową. To z kolei wpłynęło bezpośrednio na sposób rozumienia znaczenia słowa. W świetle językoznawstwa kognitywnego znaczenie słowa ujmowane jest jako struktura pojęciowa osadzona we wzorach wiedzy i doświadczeń danej społeczności językowej. Jest ono szeroko rozumiane z konceptualizacją - wyrazy „nie mają granic”, gdyż są uwikłane w cały system wiedzy, nieograniczony i niezależny od samego języka"6.

Kategoryzacja potoczna i naukowa nie wyczerpują wszystkich form porządkowania, które są istotne z punktu widzenia językowego obrazu świata. Jako alternatywa może posłużyć model pojęciowy, w którym różne sposoby kategoryzacji wzajemnie by się uzupełniały, dając wielostronny opis znaczenia słowa. Możliwości łączenia się różnych modeli kategoryzacji daje wybór formuły definicji kognitywnej (zwaną również definicją otwarta). Powołując się na w/w stwierdzenie oraz biorąc pod uwagę fakt, iż celem niniejszego artykułu jest wieloaspektowa analiza struktury konceptu STRACH właściwym wydaje się, iż opis znaczenia powinien obejmować szeroką sferę składników fakultatywnych, konotacyjnych.

Istotą koncepcji otwartej jest rozpatrywanie znaczenia w kategoriach interpretacji. Skoro znak językowy i jego znaczenie, jak stwierdza Dorota Piekarczyk, są uwikłane w dwojakie relacje - do użytkowników języka i do rzeczywistości pozajęzykowej, to szczególnie ważny wpływ na kształt definicji semantycznej ma człowiek jako podmiot tej interpretacji ${ }^{7}$. Skoro znaczenie słowa jest swoistą interpretacją desygnatu, interpretacją, która ze swej istoty jest subiektywna, to możliwe są różne spojrzenia na ten sam wycinek rzeczywistości pozajęzykowej.

Wybór definicji kognitywnej w niniejszym artykule umożliwia ukazanie sposobu, w jaki zbudowana jest struktura znaczeniowa słowa (w naszym przypadku leksemu strach): centrum znaczenia stanowi stabilny rdzeń pojęciowy (odpowiadający najczęściej znaczeniu leksykalnemu i prototypowi), a od niego wychodzą ścieżki konotacyjne. W konsekwencji językowy obraz konceptu STRACH wchłania cechy semantyczne z różnych poziomów jego werbalizacji, co z kolei wpływa na złożoność całej struktury kognitywnej.

Jak już wcześniej stwierdziliśmy, kategorie, struktury mentalne powstają pod wpływem poznawczej, interpretacyjnej postawy człowieka, dysponującego określonym zasobem wiedzy, żyjącego w określonej kulturze. Kategoryzacja pozwala rozpoznawać rodzaje rzeczy lub też doświadczenie poprzez uwypuklenie pewnych właściwości, pomniejszenie innych i ukrywanie dalszych. W poszczególnych teoriach zauważalna jest hierarchiczna struktura określonych struktur pojęciowych.

W poznawczej strukturze konceptu wyróżniany jest szereg charakterystycznych właściwości. Centrum stanowi prototyp danej kategorii, a w bliskim i coraz dalszym

${ }^{5}$ E. Tabakowska, op. cit., c. 20.

${ }^{6}$ A. Wierzbicka, Znaczenie nazw kolorów i uniwersalia widzenia, [w:] J. Bartmiński, JęzykUmyst - Kultura. Wybór prac, Warszawa 1999, s. 16.

${ }^{7}$ D. Piekarczyk, Kwiaty we wspótczesnym językowym obrazie świata, Lublin 2004, c. 23. 
otoczeniu wzorca pojawiają się coraz mniej podobne egzemplarze. Prototyp jest zatem najbardziej reprezentatywnym egzemplarzem w zbiorze elementów tworzących dany koncept. W odniesieniu do konceptu STRACH można wyróżnić jądro, stanowiące zalążek-prototyp danej struktury oraz poszczególne warstwy peryferii (bliższa, dalsza, marginalna). Znaczenia peryferyjne semantycznie rozszerzają i uszczegółowiają strukturę konceptu.

Kognitywna analiza środków językowej egzemplifikacji emocjonalnego konceptu STRACH wymusza w pierwszej kolejności prześledzenie struktury semantycznej jednostki (lub jednostek) leksykalnych rozpatrywanych jako nadrzędne - prototypowe.

Centralną część — jądro konceptu — najpełniej odzwierciedla semantyka głównego leksemu, będącego jednocześnie nazwą samego konceptu, bowiem ,werbalizowana emocja stanowi imię konceptu emocji ze względu na fakt, iż znak językowy istnieje, funkcjonuje i odzwierciedla doświadczenie tego lub innego użytkow-

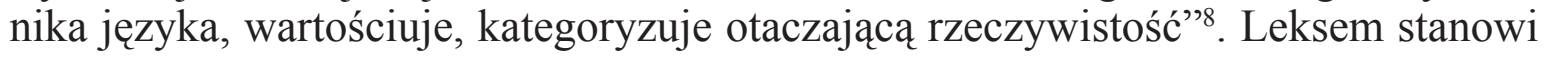
zatem najważniejszy środek werbalnej egzemplifikacji konceptu.

Dokonana przez nas analiza środków językowych pozwala stwierdzić, iż głównym leksemem reprezentującym koncept STRACH w języku ukraińskim jest rzeczownik strach. Kwestia semantyki w/w leksemu jest dość problematyczna ze względu na abstrakcyjność samego denotatu. W leksykografii ukraińskiej strach definiowany jest jako:

- , вираження, прояв тривоги, неспокою”;

- „стан хвилювання, тривоги, неспокою, викликаний чеканням чогось неприємного, небажаного”;

- негативна емоція, щзо виникає внаслідок реальної або уявної небезпеки, загрози життю, організму, особі, иінностям, щз захищаються нею”;

- „емочійний стан, щуо відображає захисну реакцію людини у прочесі переживання реальної або уявної небезпеки для його здоров'я й благополуччя”;

- „переживання, щзо викликано отриманою прямою або непрямою інформацією про реальну або уявну небезпеку, очікування невдачі";

• „фантастична істота незвичайного, страшного вигляду”.

Jak widać z przytoczonego materiału leksykograficznego, w przestrzeni semantycznej leksemu strach obecna jest ogólna cecha semantyczna "емоція", "емоційний стан". Strach jako stan jest dodatkowo konkretyzowany poprzez liczne określenia (напр. "стан хвилювання", "стан тривоги", "стан неспокою”). Pozostałe właściwości ("неприємний", "негативний”, "небезпека", "загроза", "загрозливий”, "неспокій”), mają wyraźnie wartościujący charakter i podkreślają ogólny negatywny aspekt danej emocji.

W języku ukraińskim strach określany jest również poprzez inne stany emocjonalne - swoiste „odmiany” lub „odcienie” gradacyjne strachu, rozróżniane w zależności od stopnia intensywności i długości trwania, np. "тривога", "неспокій” itd.

Oprócz wyżej wymienionych istotne znaczenie mają również takie cechy semantyczne, jak "небезпека", "загроза", konkretyzowane poprzez określenia "реальний", "уявний", "очікуваний", wskazujące na różnorodność czynników sprawczych emocji.

Leksem strach, będący jednocześnie nazwą konceptu, stanowi zatem element prototypowy, wokół którego koncentrują się pozostałe jednostki reprezentujące i utrwalające koncept STRACH w języku.

${ }^{8}$ К. О. Погосова, Конизепты эмоций в английской и русской языковых картинах мира, автореф. дисс. канд. филол. наук, Владикавказ 2007, с. 14. 
Oprócz głównego środka językowej realizacji konceptu — leksemu strach w leksykografii ukraińskiej należy odnotować szereg innych jednostek obrazujących koncept. Należą do nich:

боязкість, боязнь (побоювання), жах, жахіття, збентеження, занепокоєння, істерія, кошмар, ляк (переляк), моторошність, неспокій, острах (пострах, настрашка, острашка), паніка, полох (переполох), переживання, тривога, хвилювання.

W celu pełniejszego zobrazowania omawianej grupy semantycznej dokonamy krótkiej ich charakterystyki.

W świetle źródeł leksykograficznych боязкість оznacza "слабо виражену эмоцію страха перед чим-небудь новим, невідомим". Przyczyną powstania w/w stanu emocjonalnego jest m.in. "відсутність відповідної інформації, умінь" W związku z potencjalną możliwością powstania, rozwoju lub nastania w przyszłości określonego negatywnego zjawiska, zdarzenia lub koniecznością udziału w nim. W związku z tym боязкість zawiera również takie cechy semantyczne jak „невпевненість”.

W semantyce leksemu боязнь dominującą cechą semantyczną jest również "почуття страху", nierozerwalnie związana z kolejną, a mianowicie "очікування чогось загрозливого". Niniejszemu odczuciu może towarzyszyć dyskomfort, tzn. "відсутність покою", "напруга". Semantycznie bliskie do боязнь są również dwa pozostałe leksemy побоювання, обава.

Жax należy do najbardziej intensywnych form przejawiania emocji strachu. Spośród poszczególnych cech semantycznych główne miejsce zajmuje sem "очікування загрози". Жах ogałaca człowieka ze zdolności racjonalnego działania i podejmowania decyzji w zaistniałych okolicznościach.

Semantyka leksemu ж⿻аximm ty, które ze względu na właściwości i rozmiary fizyczne potencjalnie zagrażają człowiekowi. Innymi słowy, niebezpieczeństwo nie jest wyrażone explicite i nie zawsze ma racjonalny uzasadniony charakter.

Kolejny synonim strachu - збентеження, powołując się na definicje leksykograficzne, oznacza "стан душевного неспокою", "хвилювання", "збудження", z kolei занепокосння interpretowane jest jako "вираз тривоги, неспокою". Jak widzimy, dominującym semem jest "відсутність покою". Semy "загроза", "небезпека", chociaż również są obecne w semantyce danej jednostki to jednak nie odgrywają decydującej roli.

Кошмар - "важке", "страшне", "гнітюче видіння". Jego przyczyną jest zazwyczaj "щось неприємне". Oprócz tego uczucie opisywane jako кошмар odznacza się znacznym stopniem intensywności.

Ляк (переляк) - "несподіване почуття страху, тривоги, розпачу". Stanowi swoistą reakcję na silny, niespodziewany bodziec (np. nagły bardzo głośny dźwięk). Oprócz wymienionych, istotne znaczenie ma również czynnik krótkotrwałości.

Mотороиність definiowana jest jako "відчуття страху, жаху".

W przestrzeni semantycznej leksemu неспокій (непокій) dominującymi są następujące semy: "почуття занепокоєння", "тривога", "відсутність покою".

Leksemy ocmpax, nocmpax oznaczaja "тривожне почуття небезпеки", "стан тривоги перед можливою небезпекою", "страх", "тривожне хвилювання". Dominującą cechą semantyczną jest "відсутність покою", "небезпечність", "загроза".

Kolejne synonimy strachu - острашка, настрашка interpretowane są jako "почуття страху", "побоювання", "погрозливе попередження", "погроза страхом". 
Паніка - "раптове замішання, розгубленість або прояв страху за справжньої чи уявної небезпеки”. W przypadku leksemu паніка należy podkreślić również masowy charakter danego zjawiska oraz nagły niekontrolowany i niespodziewany sposób jego powstania.

Leksem переживання оznacza "почуття, враження людини в певний момент". Wymienione właściwości oznaczają i podkreślają krótkotrwałość i nagłość powstania danego stanu psychicznego.

Переполох — "раптовне замішання", "тривожна метушня", "переляк викликаний таким замішанням" wskazuje na nagły sposób powstania, chaos, jako rezultat czynnika niebezpieczeństwa.

Сум'ятmя pod względem semantycznym koreluje z innymi synonimami strachu i określany jest jako "загальна розгубленість, паніка", "сильне хвилювання, неспокій, тривога".

W semantyce leksemu сполох należy odnotować takie właściwości, obecne również w definicji mривогa, jak "хвилювання, що охопили багатьох".

Сум'ятmя obejmuje takie cechy jak "загальна розгубленість, паніка, замішання", "сильне хвилювання, неспокій, тривога".

Dominującą właściwością leksemu mривогa jest "неспокій, збентеження, викликані страхом перед чимось", "хвилювання, переживання". Na peryferii znajdują się takie semy jak "метушня, шарпанина, переполох" oraz "стан, що вимагає активних дій - загроза, небезпека".

Leksem хвилювання określa "стан неспокою, зумовлений страхом, радістю, тривогою, чеканням". Хвилювання оznacza również stan, mający społeczny, masowy charakter. $\mathrm{W}$ tym aspekcie semantycznie zbliżony jest do leksemu тривогa.

Przytoczone synonimy leksemu strach pozwalają wyciaggnąc następujące wnioski:

1. Wspólnym semem dla wyszczególnionych jednostek jest „Почуття загрози", „небезпека".

2. W semantyce leksemów боязкість, боязнь, пострах, острах, остраика, настрашка dominuje sem „Почуття страху”.

3. Жах, моторошність, паніка, сполох, сумяття odznaczają się wysokim stopniem intensywności.

4. W semantyce leksemów неспокій (непокій), хвилювання, тривога, переживання wyraźnie zauważalny jest sem "відсутність спокою".

5. W leksemach обава, острах dominującym cechą semantyczną jest "небезпека, загроза чого-небудь”.

6. Niespodziewany i nagły charakter jest właściwy leksemowi ляк (переляк).

7. W semantyce leksemów збентеження, переживання odczucie zagrożenia, niebezpieczeństwa nie odgrywa pierwszoplanowej roli.

Reasumując, mimo iż nie da się dokładnie ustalić zależności semantycznych pomiędzy wymienionymi rzeczownikami, to jednak na podstawie analizy przywołanych jednostek leksykalnych można wydzielić ogólne cechy semantyczne, takie jak:

- intensywność,

- nagły niespodziewany charakter,

- brak spokoju,

- trwałość w czasie,

- oczekiwanie,

- stan,

- niebezpieczeństwo,

- zagrożenie. 
Przytoczone powyżej różnorodne „odmiany” i „odcienie” emocji strachu traktujemy jako jego synonimy. W związku z tym, iż poszczególne leksemy koncentrują się wokół głównej, nadrzędnej jednostki, stanowią one bliższą warstwę peryferii w strukturze emocjonalnego konceptu STRACH.

Jak już stwierdziliśmy powyżej wybór definicji kognitywnej w niniejszym artykule umożliwia ukazanie sposobu, $\mathrm{w}$ jaki zbudowana jest struktura znaczeniowa słowa: centrum znaczenia stanowi stabilny rdzeń pojęciowy, a od niego wychodzą ścieżki konotacyjne. W konsekwencji językowy obraz konceptu STRACH wchłania cechy semantyczne z różnych poziomów jego werbalizacji, co z kolei wpływa na złożoność całej struktury kognitywnej.

Kolejny element złożonej struktury konceptu STRACH stanowi dalsza warstwa jego peryferii, obejmująca jednostki, w semantyce których dominują mniej prototypowe semy w stosunku do jednostki nadrzędnej konceptu.

$\mathrm{Na}$ podstawie przeanalizowanego materiału językowego dalsza części peryferii obejmuje znaczącą ilość jednostek językowych, wśród których można wymienić:

- leksemy odznaczające się mniejszą częstotliwością użycia, np. встряска (разг.), опаска (разг.).

- leksemy wskazujące na obiekty lub zjawiska, będące źródłem powstania етосji strachu: страхіття, страховиддя, страховидло, страшидло, страшило, страховисько страховище, страхота;

- leksemy wskazujące na powstanie lub zamiar wywołania określonego stanu emocjonalnego: лякання;

- leksemy wskazujące na stan emocjonalny: збентеженість, стурбованість, моторошність и т.д.;

- leksemy wskazujące na rysy charakteru jednostki: богобійність, боягузливість, боязливість, боязкість, лякливість, страхітливість, страхітність; leksemy nazywające ludzi będących pod wpływem danej emocji: боягуз, боягузка, боязливець, панікер, панікерка;

Przywołane przykłady, należące do dalszego kręgu peryferii nie wyczerpująjego objętości. Znaczna część należy do marginalnej warstwy peryferii. Ze względu na powiązanie konceptu STRACH z innymi strukturami mentalnymi niniejsza część jego struktury obejmuje zróżnicowane pod względem semantycznym jednostki, np.

- leksemy wskazujące na naruszenie równowagi psychicznej jednostki: безладдя, неприємність, напруга, мука, незручність, дискомфорт, страждання, метушня, сум'яття, напруження;

- leksemy wskazujące na zmiany w fizjonomii, zachowaniu człowieka: коливання, несталість, плутанина, дратівливість, нервозність, струс, зворушення;

- leksemy nazywające ludzi, działalność których rozpatrywana jest jako czynnik zagrożenia i niebezpieczeństwa: бандюг, ворог, загарбник, злочинець, кривдник, лобуряк, супротивник, терорист;

- leksemy wskazujące na źródło - czynnik sprawczy emocji strachu, naruszające fizyczna, psychiczną, materialną równowagę. Niniejsza grupa słów obejmuje jednostki, charakteryzujące się abstrakcyjnością znaczenia, np. деградаиія, криза, турботи, катастрофа, хвороба, втручання, насильство, агресія, агресивність, смерть, війна, знищення, епідемія, конфлікт, загибель, нестійкість, нестабільність, дестабілізаџія, неприємність, злочинність, безробіття, біль, стрес, напруженість, бідність, убозтво;

W strukturze marginalnej warstwy peryferii zauważalne są liczne jednostki językowe, należące do struktury innych konceptów, co potwierdza fakt o powiązaniu 
konceptu STRACH z innymi strukturami mentalnymi. Przeanalizowany materiał językowy daje podstawy do stwierdzenia, iż wybrany przez nas fragment językowego obrazu świata jest w ścisłej korelacji z takimi konceptami, jak:

- koncept BÓL,

- koncept CHOROBA,

- koncept TERRORYZM,

- koncept PRACA,

- koncept PRZEMOC,

- koncept AGRESJA,

- koncept ŚMIERĆ,

- koncept WOJNA itd.

Przeprowadzona analiza pozwala ustalić, iż emocjonalny koncept STRACH w języku ukraińskim reprezentowany jest poprzez znaczącą ilość jednostek leksykalnych. Ze względu na zawężone ramy niniejszej pracy skupiliśmy się jedynie na grupie semantycznej, zawierającej rzeczowniki. Przywołane przykłady nie wyczerpują jednak wszystkich możliwości egzemplifikacji konceptu STRACH. Skoro zgodnie z założeniami językoznawstwa kognitywnego znaczenie słowa jest swoistą interpretacją desygnatu, interpretacją, która ze swej istoty jest subiektywna, to możliwe są różne spojrzenia na ten sam wycinek rzeczywistości pozajęzykowej, co z kolei stanowi punkt wyjścia do dalszych badań, w szczególności o charakterze konfrontatywnym, dzięki którym możliwe jest prześledzenie sposobów interpretacji i kategoryzacji tego samego wycinka rzeczywistości przez przedstawicieli różnych kultur i różnych systemów językowych. 